\title{
Improving the quantitative and qualitative of Manfalouty pomegranate cultivar.
}

\author{
Ibrahim, R.A. , M.T. El-Mahdy, M.A.M. Taha and M.M. Shaaban \\ Pomology Department, Faculty of Agriculture, Assiut University, Assiut, Egypt
}

\begin{abstract}
One of the major physiological disorders for pomegranate cultivation is the excessive of fruit cracking. lately, a pomegranate physiological syndrome called 'aril paleness' in which a part or all of the arils appear discoloration, affect the quality of fruit and such fruits are not desired for consumer. The present research designed to evaluate the effects of methyl jasmonate (MJ), humic acid (HA) and potassium $(\mathrm{K})$ on reducing these disorders and improving fruit quality. Seven treatments including MJ (5 and $10 \mathrm{ppm}$ ), HA (50 and $100 \mathrm{ppm}$ ), Liquid $\mathrm{K}$ (1 and 2\%) and control, were tested on pomegranate trees spraying three times, at the beginning of flowering (during April), after full bloom (end of June) and before harvesting (mid-September), during the two seasons of study. Different parameters including yield, fruit cracking and fruit quality were measured. The obtained results indicated that spraying $\mathrm{HA}$ at $100 \mathrm{ppm}$ and $\mathrm{MJ}$ at $10 \mathrm{ppm}$ are considered the best in their effects on the yield components, fruit quality and anthocyanin content, however for decreasing the fruit cracking, it could be recommended to spray the fruits with $\mathrm{K}$ at $1 \%$ or $\mathrm{MJ} 10 \mathrm{ppm}$ compared to the rest of the treatments.
\end{abstract}

Keywords: Methyl jasmonate, Humic acid, Potassium, Anthocyanin, Fruit splitting

\section{Introduction}

Pomegranate (Punica granatum L.) is one of the most important fruit trees in tropical and sub-tropical regions and grown successfully in Egypt, not only in the old lands but also in the newly reclaimed lands. It is an important commercial fruit crop that is extensively cultivated in many parts of Asia, North Africa, the Mediterranean and the Middle East regions (Sarkhosh et al., 2006). Pomegranate fruits are extensively consumed fresh or managed into juice, jams, syrup and sauce. The edible part

\footnotetext{
*Corresponding author: R.A. Ibrahim

Email: rashad4274@yahoo.com

Received: January 12, 2021;

Accepted: January 28, 2021;

Published: February 1, 2021.
}

(arils) of fruit is about 55-60\% of the total fruit weight and consists of about $75-85 \%$ juice and 15-25\% seeds (Pareek et al., 2015). Manfalouty is considered as the most imperative pomegranate cultivars established successfully in Upper Egypt and particularly in Assiut Governorate which ranks the second in the area compare to another fruit crops. The increasing amount of pomegranates fruit which spread were recently augmented in the last decade, due to its highly content of antioxidants, some vitamins and minerals which exhibit protective effects against many diseases including different cancers, vascular disorders, and inflammatory problems (Heber 
et al., 2006; Ozgen et al., 2008; O’Grady et al., 2014).

Fruit cracking is the most serious problem influencing the productivity of pomegranate trees in economic terms. It is a physiological disorder that occurs because of the different growth rats between skin and flesh of fruit (Yilmaz and Özgüren, 2009). There are many factors that cause fruit cracking such as unbalanced irrigation, hot dry weather, soil moisture, climatic conditions, tree nutrition and cultivars (Abd- El-Rahman, 2010; Kumar et al., 2010; Sheikh and Manjula, 2012; Hegazi et al., 2014). This problem caused a significant loss in the productivity of some pomegranate cultivars and may reach more than $50 \%$ in some cultivars (Sheikh and Manjula, 2012).

The use of phytohormones, organic materials and growth regulators during production stages has been considered as a new policy to improve different crop quality parameters and decrease the vulnerability to postharvest losses (Kucuker et al., 2014; Ahammed et al., 2015; Asghari and Zahedipour 2016; Sun et al., 2019). Jasmonic acid signaling molecules in plants make the plant responsive to various biotic and abiotic stresses, involved in fruit ripening, control pollen maturation and accidental damage in plants (Jin et al., 2009; Meng et al., 2009; Wasternack and Hanse, 2013; Zhou et al., 2013). Meaningfully, methyl jasmonate (MJ) application on fruit increases the red color, anthocyanin and $\beta$ carotene contents, and several phenolic compound gaining, and the ethylene and lots of ester compound (Wang and Zheng, 2005; Wang et al., 2008; Mukkun and Singh, 2009). Humic acid is a multifaceted organic material resulting from the decomposition of plant matter that exists as a mixture of soluble substances. These organic supplements can be used to adjust hormone levels, improve nutritional uptake, and enhance stress tolerance (Khattab et al., 2012; Lotfi et al., 2015; Moghadam, 2015). It also can be used for maintainable agriculture with the aim of diminish the cost of production and help protect the environment through replacement it instead of chemical fertilizers instead of it (Hatami et al., 2018).

Potassium is one of the supreme vital macro elements which highly movable in plants at all levels. It plays a most important role in enzyme activation, protein synthesis, stomatal function photosynthesis and transport of metabolites. Potassium develops fruit quality by increasing fruit size, juice content, color and juice flavor (Tiwari, 2005; Ashraf et al., 2010).

Therefore, the current study was intended to evaluate the effect of methyl jasmonate (MJ), humic acid (HA) and potassium (K) spraying on yield components, fruit splitting and some fruit quality parameters of Manfalouty pomegranate cultivar.

\section{Materials and Methods}

\subsection{Plant materials and treatments}

The present study was executed during two successive seasons of 2018 and 2019 on Manfalouty pomegranate cultivar grown at the Experimental Orchard of Faculty of Agriculture, Assiut University. The soil was heavy loam. Regular agricultural managements were applied to all experimental trees as recommended. The trees space was $5 \times 5$ apart and they were 40 years old at the start of the experiment. Twenty-eight uniform trees were selected and divided into seven treatments 
including the control, each treatment was executed on four trees (Replicates). Seven treatments category were as follows

1- Spraying methyl jasmonate (MJ) at $5 \mathrm{ppm}$

2- Spraying methyl jasmonate (MJ) at $10 \mathrm{ppm}$.

3-Spraying Humic acid (HA) at $50 \mathrm{ppm}$

4- Spraying Humic acid (HA) at $100 \mathrm{ppm}$.

5- Spraying Liquid Potassium (K) at $1 \%$

6- Spraying Liquid Potassium (K) at $2 \%$.

7- The control (water only).

Treatments were dissolved according to the pre-mentioned concentrations. The trees were sprayed with knapsack sprayer. A total volume of $20 \mathrm{~L}$ was adequate for spraying 4 trees until runoff. The spraying treatments executed three times, at the beginning of flowering (during April), after full bloom (end of June) and before harvesting (mid-September), through the two seasons. The subsequent parameters were recorded.

\subsection{Plant measurements}

\subsubsection{Vegetative growth parameters}

Five mature leaves on tagged shoots were picked for calculating the leaf area utilizing the succeeding equation outlined by (Ahmed and Morsy, 1999).

Leaf area $\left(\mathrm{cm}^{2}\right)=0.41(\mathrm{~L} x \mathrm{~W})+1.83$

Where: $\mathrm{L}=$ leaf length $(\mathrm{cm}), \mathrm{W}=$ leaf width $(\mathrm{cm})$

The total chlorophyll content in fresh leaves was determined as said by the method defined by Betemps (2012) using Minolta chlorophyll Meter Spad. 502 (Minolta Camera, LTD Japan). Equation shows how total chlorophyll content is calculated

$\mathrm{Chl}_{a+b}=22.12 \mathrm{E}_{652}+2.71 \mathrm{E}_{665}$

Where: $\mathrm{E}$ is the rate of absorption of the sample at the wavelength of the subtitle E. for example, $E_{652}$ is the absorption at a wavelength of $652 \mathrm{~nm}$.

\subsubsection{Yield components}

The fruits of all treated trees were picked at mid-October in the two seasons. Fruits per tree were counted and weighted to estimate the total number of fruits and yield weight (kg/tree), and then the fruits were graded into three grades as following:

- $\quad$ Grade I (fruits of 400-500 g or above in the weight)

- Grade II (fruits of 300-400 $\mathrm{g}$ in the weight)

- $\quad$ Grade III (fruits of 200-300 g or less in the weight)

The commercial and non-commercial fruits were estimated and the percentage was calculated. As well as cracked fruits were sorted, counted, weighted and the percentage of fruit splitting was calculated relative to the total yield weight or the total number of fruits.

\subsubsection{Physical properties}

Samples of four fruits per tree were collected randomly and the fruit weight was measured using an electronic balance so as to determine peel and arils weight percentage, fruits were peeled and the weight of total arils and peel were estimated, and then the percentage of arils relative to the fruit weight was calculated. Also, the 100 arils weight (g) and Juice volume/100 arils (ml) were calculated.

\subsubsection{Fruit sensory attributes}

Total acidity was determined using titration by $\mathrm{NaOH}$ at $0.1 \mathrm{~N}$ and phenolphthalene as an indicator and then, expressed as citric acid, along with the subsequent equation (A.O.A.C., 1995):

Acidity $y_{0}=\frac{\text { VaOH volume in trtration X VaOH molarity e equivalent weight of citric acid }}{1000 \text { xsample volume }} \times 100$

Where: Equivalent weight of citric acid $=64$, $\mathrm{NaOH}$ molarity $=0.1 \mathrm{M}$, Sample vol. $=5 \mathrm{ml}$. 
Total soluble solids (TSS \%) was measured using the hand refractometer and then, TSS/Acid ratio was calculated. The percentage of reducing and total sugars in juice was determined, according to A.O.A.C. (1995).

2.2.5. Total anthocyanin content (TAC) of peel and juice

Extracts were prepared by the method described by( Onayemi et al. 2006). $1 \mathrm{~g}$ fruit skin samples were pulverized with $20 \mathrm{ml}$ of 85 Ethanol and 1.5 M HCL (by volume) solution. The samples were covered and kept overnight in the deep freeze. The extracts were completed to $50 \mathrm{ml}$ of the solvent and then absorbance of the solution was measured at a wave length of $530 \mathrm{~nm}$, using spectrophotometer (Unico 1200-USA). Result is expressed as $\mathrm{mg} / 100 \mathrm{~g}$ of fresh fruit. Total santhocyanin was calculated using the succeeding equation developed by( Lees and Franci 1971).

Total anthocyanin $(\mathrm{mg} / 100 \mathrm{~g}$ fruit skin $)=\frac{A 530 \times \mathrm{V}}{98.2 \times \mathrm{W}}$

Where: $\mathrm{A}_{530}$ is the rate of absorption of the sample at the wavelength of the subtitle A. for example, $\mathrm{A}_{530}$ is the absorption at a wavelength of $530 \mathrm{~nm}$., $\mathrm{V}=$ total volume of extract $(\mathrm{ml}), \mathrm{W}=$ weight of fresh sample $(\mathrm{g})$,

\subsection{Statistical analysis}

The experiment was set as a complete randomized blocked design (CRBD) including seven treatments and four replicates per each treatment. Combined analysis over seasons was used. The analysis of variance (ANOVA) was applied using Proc Mixed of SAS package version 9.2 (SAS, 2008) and means were compared by using the revised L.S.D. values at
$5 \%$ level of the probability (Snedecor and Cochran, 1990).

\section{Results}

\subsection{Vegetative growth parameters}

The results showed that all the treatments had a positive effect and caused a significant increase in the leaf area compared to the control during the two seasons of study (Fig. 1). In addition, the best influencing treatment on the leaf area was HA at 100 ppm followed by potassium at $1 \%, \mathrm{MJ}$ at $5 \mathrm{ppm}$, and $\mathrm{MJ}$ at $10 \mathrm{ppm}$, which gave an average leaf area of $6.99,6.97,6.63$ and $6.60 \mathrm{~cm}^{2}$ with an increment of 16.9, 16.6, 10.9 and $10.4 \%$ over the control treatment, respectively, with no significant differences between them. Whereas, the lowest impact aspect was the control treatment which gave $5.98 \mathrm{~cm}^{2}$ as an average of both seasons.

For the total chlorophyll content, the results represented that $\mathrm{K}$ at $2 \%$ gave the highest value of total chlorophyll content, followed by the $\mathrm{HA}$ at $50 \mathrm{ppm}$ without significant differences between them. They gave 71.2, 70.8 , with an increment of $25.8,25.1 \%$ over the control, respectively as an average of the two seasons of the study, whereas the control treatment gave the lowest value (Fig. 1). In general, the $\mathrm{K}$ at $2 \%$ treatment and $\mathrm{HA}$ at 50 ppm are considered the best in their effect on the total chlorophyll attribute compared to the rest of the treatments. 


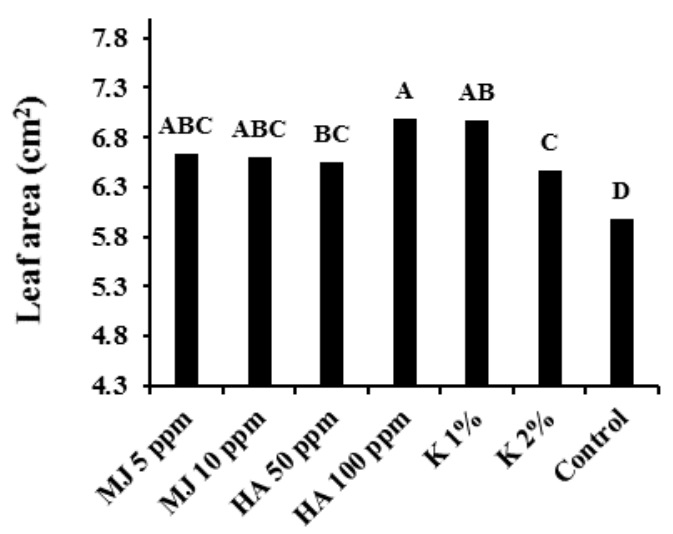

(A)

Treatments

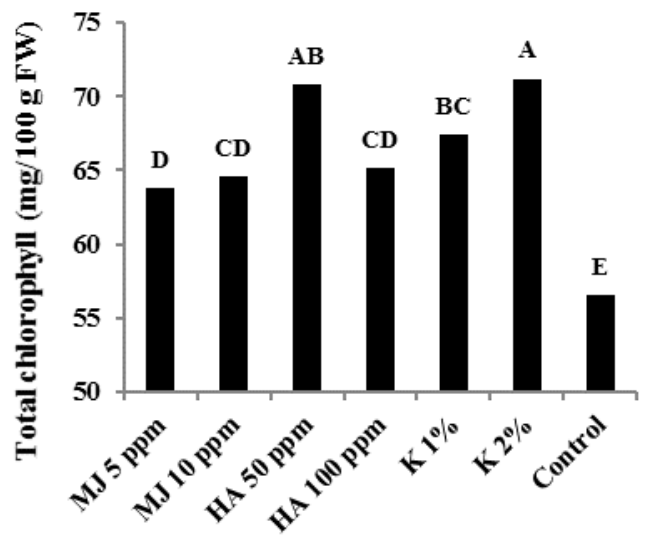

(B)

Treatments

Figure 1. Effect of (MJ), (HA) and (K) spraying on vegetative growth: (A) leaf area $\left(\mathrm{cm}^{2}\right)$, (B) total chlorophyll (mg/100 $\mathrm{g}$ fresh weight) of Manfalouty pomegranate cultivar during 2018 and 2019 seasons.

\subsection{Yield components and fruit splitting}

\subsubsection{The yield weight ( $\mathrm{kg} /$ tree)}

The results displayed that all the treatments had a significant effect on the total yield/tree compared to the control (Fig. 2). Importantly, the highest yield $(109.3 \mathrm{~kg} / \mathrm{tree})$ was obtained from HA at $100 \mathrm{ppm}$ treatment, which led to $53.9 \%$ increase over the control $(71.0 \mathrm{~kg} /$ tree $)$ as an average of the two successive seasons, followed by each of $\mathrm{MJ}$ at $5 \mathrm{ppm}, \mathrm{K}$ at $1 \%$, MJ at $10 \mathrm{ppm}$, and then potassium at $2 \%$ treatments. They recorded 100.3, 94.8, 93.4 and $92.3 \mathrm{~kg} /$ tree with an increment of 41.3 , $33.5,31.5$ and $30.0 \%$ over the control, respectively, while the lower impact influences were $\mathrm{HA}$ at $50 \mathrm{ppm}$ treatment, which gave $(82.4 \mathrm{~kg} /$ tree $)$. On the other side, the control trees produced the lowest yield.

The same Figure reported that HA at 100 ppm treatment caused a significant increase in the yield of grade I, II and a decrease in cracking fruits compared to other treatments and control as an average for the two successive seasons. The values of yield of grade I and II were 54.3 and $29.9 \mathrm{~kg} /$ tree with an increment of 78.0 and $77.98 \%$ over the control, respectively. As for the yield of grade II, III and cracking fruits, the results revealed that there were no significant differences between HA at $100 \mathrm{ppm}$ and MJ at $5 \mathrm{ppm}$, whereas HA at $50 \mathrm{ppm}$ gave the lowest values for yield of grade II and III and the highest values for cracking fruits compared to other spraying treatments.

\subsubsection{Commercial, Non-commercial fruits and fruit splitting \%}

The results presented in Fig. 3 indicated that all the treatments resulted in a significant increase in the percentage of commercial fruits and a significant decrease in the percentage of non-commercial fruits compared to the control. 


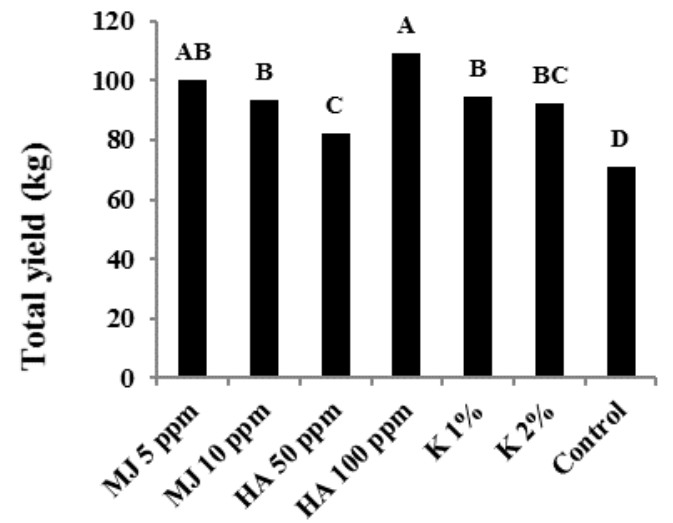

(A)
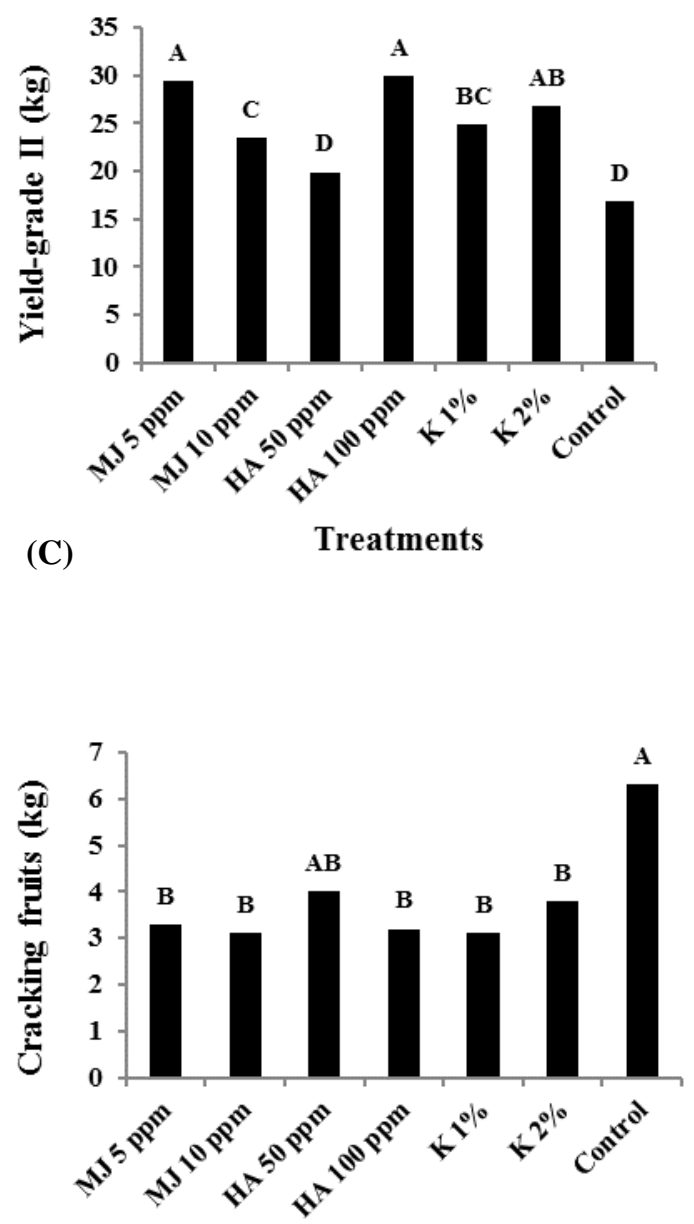

(E)

Treatments

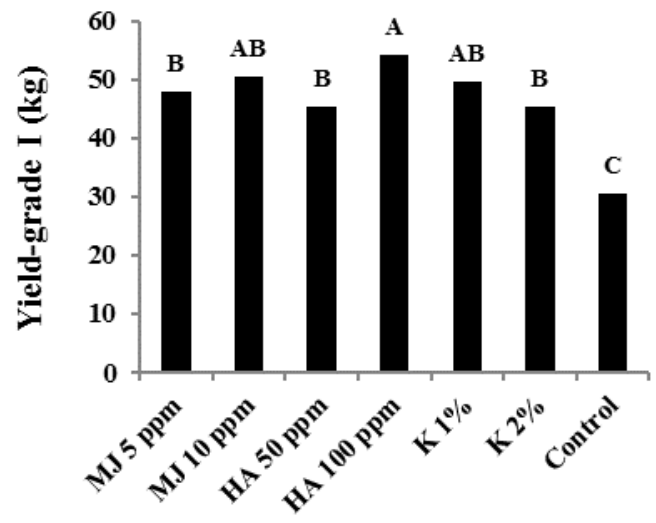

(B)

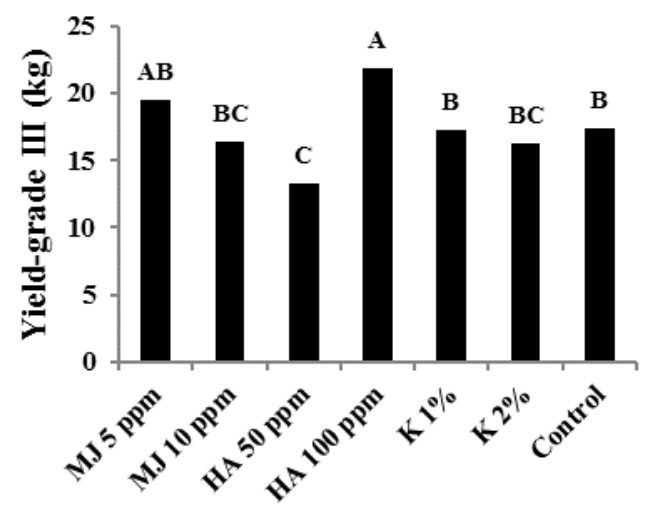

(D)

Figure 2. Effect of (MJ), (HA) and (K) spraying on the yield (kg): (A) total yield, (B) yield-grade I, (C) yield-grade II, (D) yield-grade III and (E) cracking fruits of Manfalouty pomegranate cultivar during 2018 and 2019 seasons. 
As for fruit splitting percentage, the results indicated that all the treatments caused a reduction in the percentage of fruit cracking compared to the control, and these differences were significant as an average of two successive seasons. Likewise, the $\mathrm{K}$ at $1 \%$ treatment is considered the best in obtaining the least fruit cracking percentage compared to other spraying treatments and the control. It gave $4.5 \%$ of splitting fruits with a decrement of $57.1 \%$ than the control, followed by each of $\mathrm{HA}$ at $100 \mathrm{ppm}, \mathrm{MJ}$ at $5 \mathrm{ppm}, \mathrm{K}$ at $2 \%$ and $\mathrm{MJ}$ at $10 \mathrm{ppm}$ with no significant differences between them, while, HA at $50 \mathrm{ppm}$ gave the higher values (7.2\%) compared to other spraying treatments as an average of the two seasons. On the other side, the control treatment produced the highest value of splitting fruits.

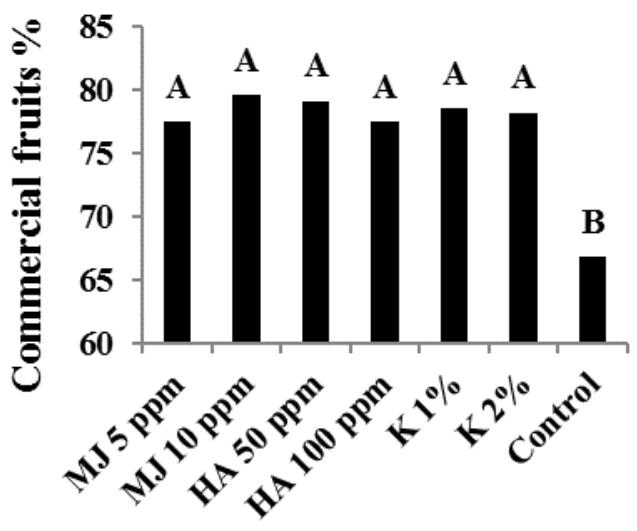

(A)

Treatments

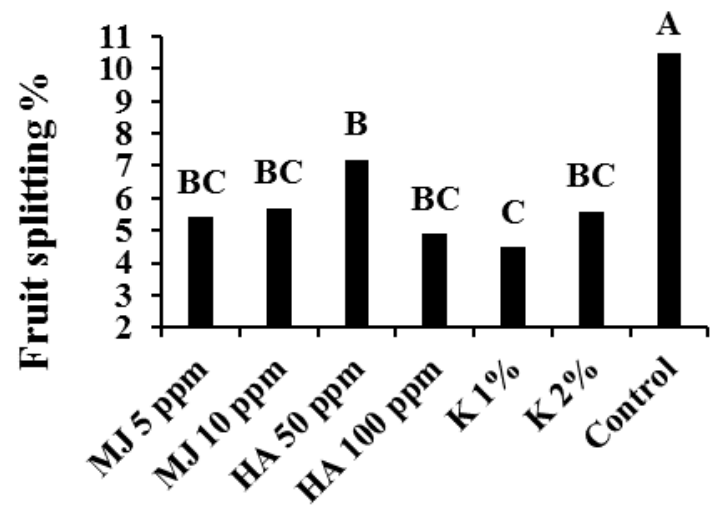

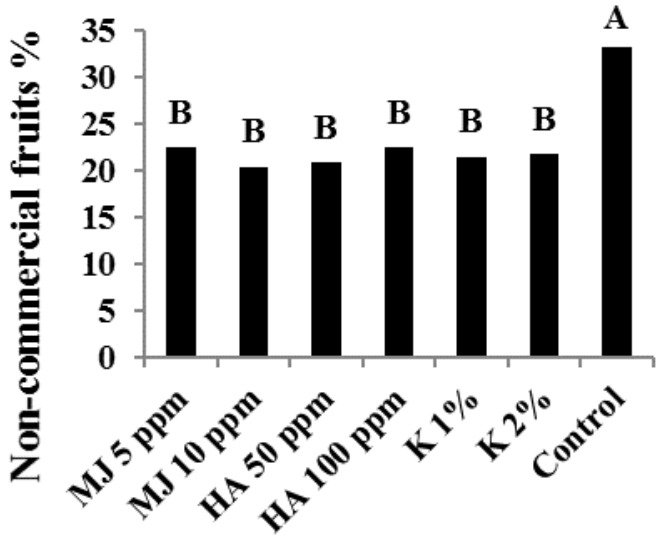

(B)

Treatments

Treatments

Figure 4. Effect of (MJ), (HA) and (K) spraying on (A) commercial fruits \%, (B) noncommercial fruits $\%,(\mathrm{C})$ fruit splitting $\%$ of Manfalouty pomegranate cultivar during 2018 and 2019 seasons. 


\subsection{Physical properties}

\subsubsection{Fruit weight (g)}

The results revealed that all the treatments had a positive effect on the average fruit weight compared to the control, and these effects were significant (Fig. 4). Moreover, the best treatment in its effect on the average fruit weight was the MJ at $10 \mathrm{ppm}$, which gave the highest enormousness average fruit weight (420.7 g) with an increment of $23.5 \%$ over the control, followed by HA at $50 \mathrm{ppm}$ which gave an average fruit weight of $397.5 \mathrm{~g}$ with an increment of $16.7 \%$, whereas, the control treatment gave the lowest value as an average of the two seasons of study. In addition, MJ at $10 \mathrm{ppm}$ treatment produced a significant increase in the average fruit weight of grade I and II compared to other treatments and the control as an average for the two successive seasons (Fig. 4). The values of the average fruit weight of grade I and II were 540.1 and
$381.7 \mathrm{~g}$, which gave an increment of 26.0 and $7.8 \%$ over the control, respectively, followed by $\mathrm{HA}$ at $50 \mathrm{ppm}$ treatment which gave the average fruit weight 470.1 and $379.1 \mathrm{~g}$, respectively, whereas $\mathrm{K}$ at $1 \%$ treatment gave the lower value compared to other spraying treatments. On the other side, the control treatment gave the lowest value as an average of the two seasons of study. For fruit weight of grade III, the best treatment was MJ at $5 \mathrm{ppm}$ which gave the fruit weight of $312.6 \mathrm{~g}$ with an increment of $19.3 \%$ over the control, followed by each of HA at $100 \mathrm{ppm}$ and HA at $50 \mathrm{ppm}$ which gave the values of 312.5 and $306.3 \mathrm{~g}$, respectively, while the $\mathrm{K}$ at $1 \%$ treatment obtained the lowest value as an average of the two seasons of study. In general, the MJ at 10 ppm and then HA at $50 \mathrm{ppm}$ treatments are considered the superlative in their effect on the average fruit weight compared to other treatments.

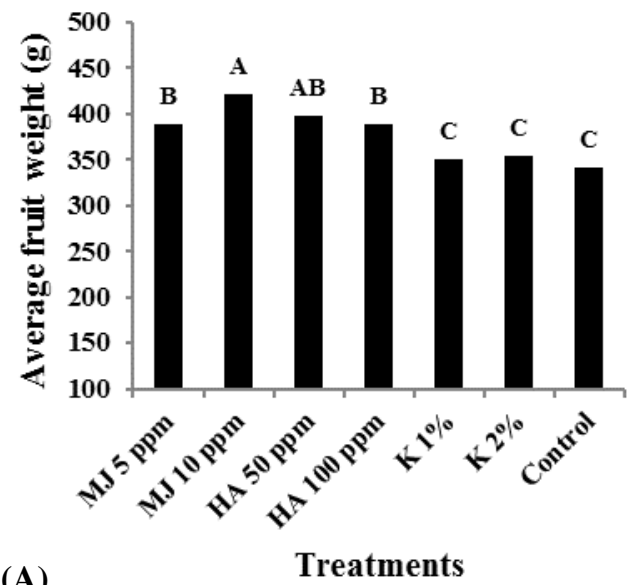

(A)
Treatments

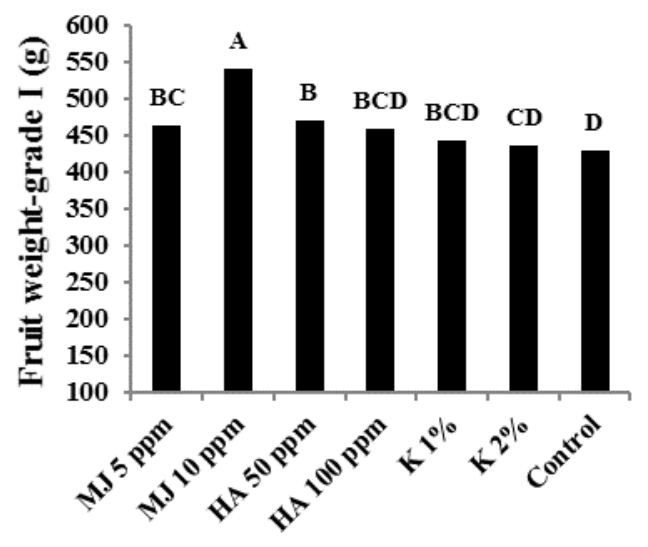

(B)
Treatments 

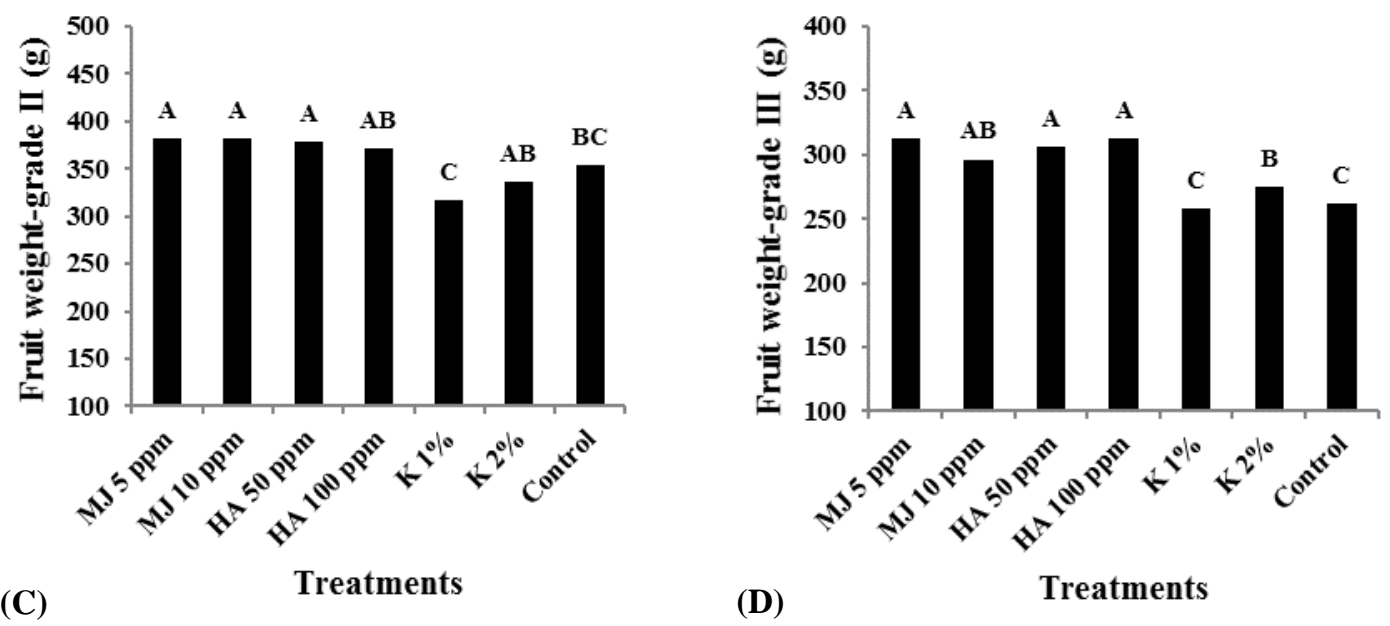

Figure 4. Effect of (MJ), (HA) and (K) spraying on the fruit weight (g): (A) average fruit weight, (B) fruit weight-grade I, (C) fruit weight-grade II and (D) fruit weightgrade III of Manfalouty pomegranate cultivar during 2018 and 2019 seasons.

\subsubsection{Fruit peel and arils \%}

Fig. 5 showed that there were no significant differences between $\mathrm{HA}, \mathrm{K}$ and the control treatments in their effects on fruit peel \%. On the other side, $\mathrm{MJ}$ at both concentrations decreased fruit peel \% comparing to the rest of treatments. The same Figure showed that there was a significant decrease in the fruit arils \% during the two seasons of study. MJ at $10 \mathrm{ppm}$ treatment gave the highest significance of fruit arils percentage compared to the other treatments and the control followed by $\mathrm{MJ}$ at 5 ppm treatment. They gave the highest fruit arils \% (61.7 and 54.9\%) compared to other treatments and the control as an average of the two successive seasons.

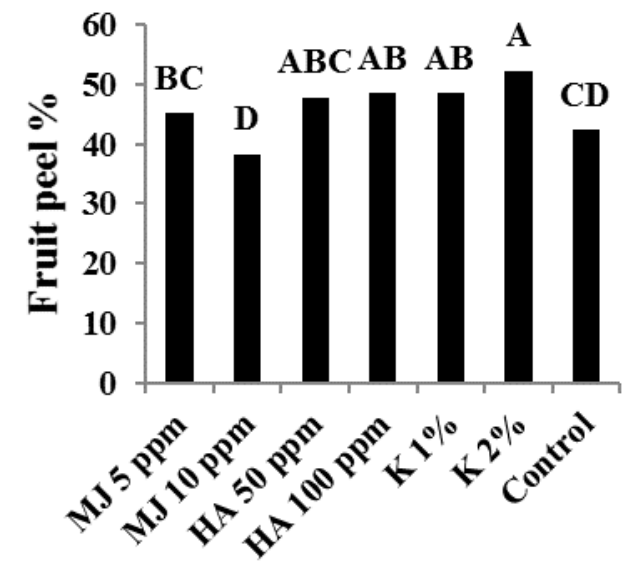

(A)
Treatments

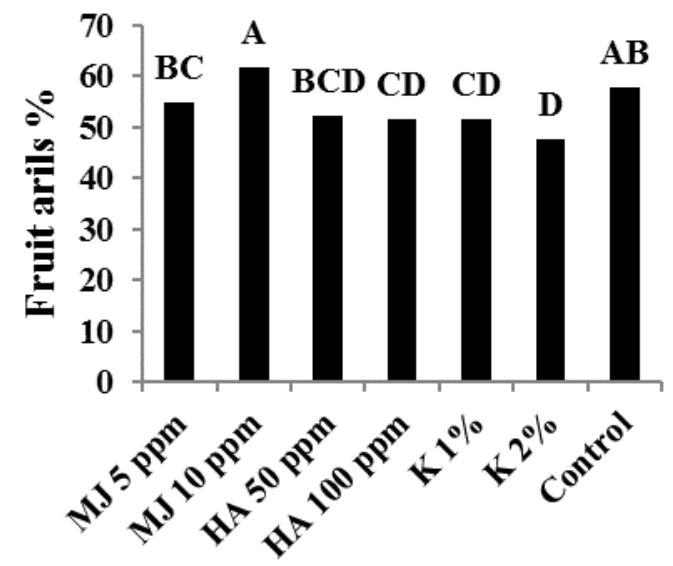

(B)

\section{Treatments}

Figure 5. Effect of (MJ), (HA) and (K) spraying on (A) fruit peel \%, (B) fruit arils \% of Manfalouty pomegranate cultivar during 2018 and 2019 seasons. 
3.3.3. 100 arils weight (g) and Juice volume $\left(\mathrm{cm}^{3}\right)$

It is clear from Fig. 6 that the best treatments in this respect were $\mathrm{MJ}$ at $5 \mathrm{ppm}$ and $10 \mathrm{ppm}$, $\mathrm{HA}$ at $50 \mathrm{ppm}$ and then $\mathrm{K}$ at $2 \%$. They recorded $35.5,35.5,35.3$ and $33.3 \mathrm{~g}$ with an increment of $8.6,8.6,8.0$ and $1.8 \%$, respectively. The differences between the above-mentioned treatments were not significant.

Similarly, it is obvious that there were a significant difference between $\mathrm{MJ}$ at 5, and 10 $\mathrm{ppm}$ and $\mathrm{HA}$ at $50 \mathrm{ppm}$ treatments in their effect on juice volume of 100 arils compared to the control.

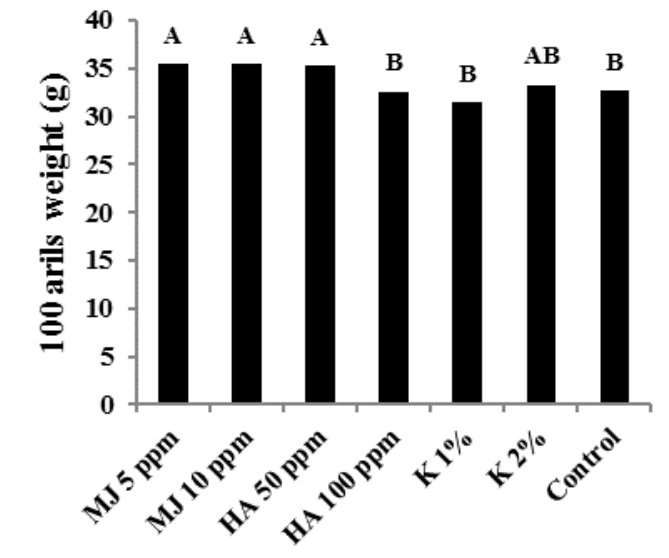

(A)
Treatments

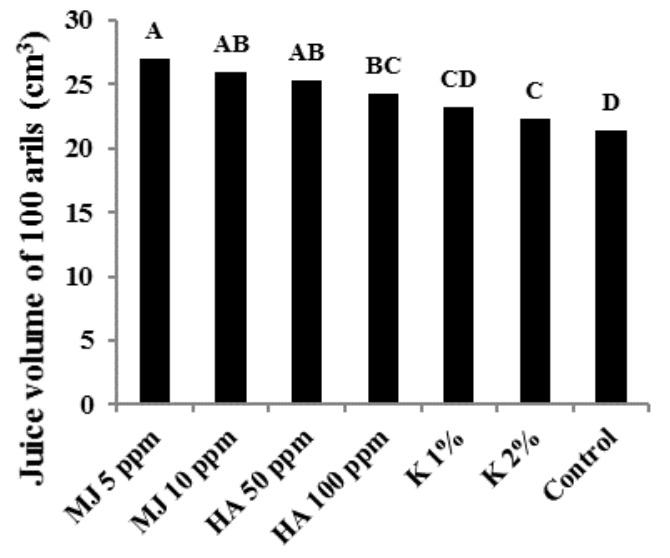

(B)
Treatments

Figure 6. Effect of (MJ), (HA) and (K) spraying on (A) 100 arils weight (g), (B) juice volume of 100 arils $\left(\mathrm{cm}^{3}\right)$ of Manfalouty pomegranate cultivar during 2018 and 2019 seasons.

They recorded values of 27.0, 25.9 and 25.3 $\mathrm{cm}^{3}$ with an increment of 26.2, 21.0 and $18.2 \%$, respectively, followed by $\mathrm{HA}$ at 100 ppm treatment which recorded value of 24.3 $\mathrm{cm}^{3}$ with an increment of $13.6 \%$ over the control, while the control treatment recorded the lowest value $\left(21.4 \mathrm{~cm}^{3}\right)$ as an average of the two successive seasons.

\subsection{Fruit sensory attributes}

3.4.1. Total soluble solids (TSS) $\%$, total acidity \% and TSS/acid ratio

Data illustrated in Fig. 7 showed that ,all the treatments caused a significant increase in the TSS $\%$ compared to the control during the two successive seasons. In addition, there were no significant differences between MJ, HA and K at $2 \%$ treatments in their effect on the TSS $\%$. The most effective treatments respecting the TSS $\%$ were $\mathrm{HA}$ at $100 \mathrm{ppm}, \mathrm{MJ}$ at $5 \mathrm{ppm}$, MJ at $10 \mathrm{ppm}$ and $\mathrm{K}$ at $2 \%$. The percentages of these later treatments were 17.4, 17.2, 17.1 and $17.0 \%$ as an average of the two seasons of study, respectively, while the control treatment gave the lowest value (15.8\%).

Furthermore, $\mathrm{K}$ at $2 \%$ treatment gave the lowest acidity percentage (1.30\%) compared to the other treatments, followed by MJ at $5 \mathrm{ppm}$ treatment which gave a total acidity percentage of $1.57 \%$, while the control gave the highest value of total acidity percentage (2.14\%). Also, there were no significant differences between each of $\mathrm{HA}$ at $50 \mathrm{ppm}, \mathrm{MJ}$ at $10 \mathrm{ppm}$, 
$\mathrm{HA}$ at $100 \mathrm{ppm}$ and $\mathrm{K}$ at $1 \%$ treatments in their effect on the total acidity percentage of Manfalouty pomegranate cultivar as an average of the two successive seasons.

Data found in such Fig. showed that the highest ratio was taken from $\mathrm{K}$ at $2 \%$ treatment followed by $\mathrm{MJ}$ at $10 \mathrm{ppm}$ treatment. They gave ratio of 13.5 and 12.3 , respectively, while the control gave the lowest ratio (8.1) as an average of the two studied seasons. Moreover, there were no significant differences between $\mathrm{MJ}$ at $5 \mathrm{ppm}$ and $\mathrm{HA}$ at $100 \mathrm{ppm}$ treatments, as well as between HA at 50 ppm and $\mathrm{K}$ at $1 \%$ treatments in their effect on TSS/acid ratio.

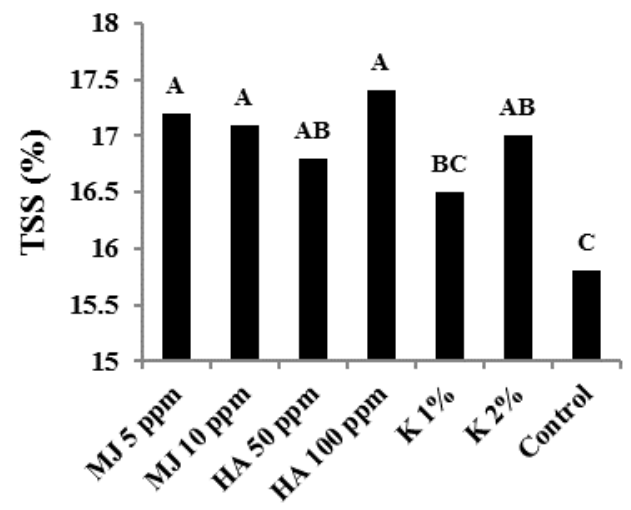

(A)

Treatments

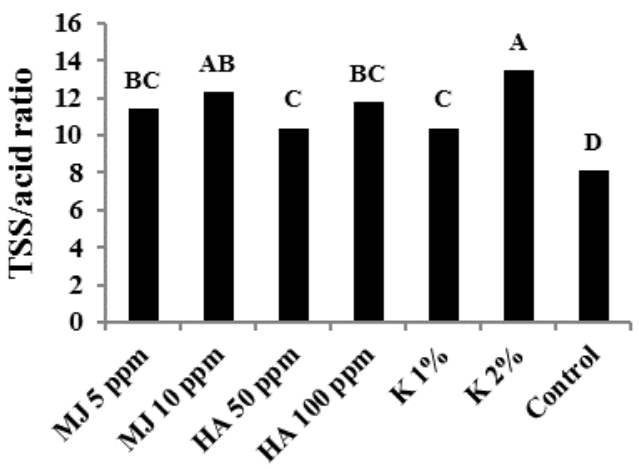

(C)

\section{Treatments}

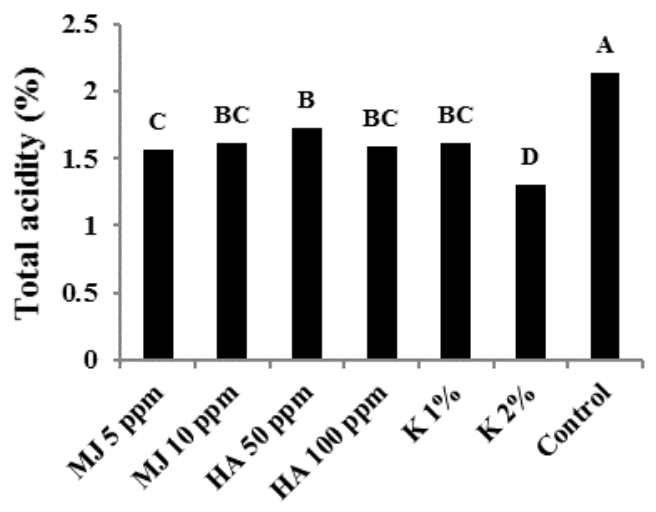

(B)

Figure 7. Effect of (MJ), (HA) and (K) spraying on fruit sensory attributes: (A) TSS $\%$, (B) total acidity, (C) TSS/acid ratio of Manfalouty pomegranate cultivar during 2018 and 2019 seasons.

\subsubsection{Sugars content}

The results showed that all the treatments had a positive effect and caused a significant increase in total and reducing sugars \% compared to the control treatment, however, there were no significant effect between most of the treatments for non-reducing sugars \% during the two seasons of study (Fig. 8). The 
best influencing treatment on the reducing sugars $\%$ was $\mathrm{HA}$ at $100 \mathrm{ppm}$ which gave an average of 13.88 with an increment of $27.0 \%$ over the control followed by MJ at $10 \mathrm{ppm}$ and $\mathrm{MJ}$ at $5 \mathrm{ppm}$ treatments which gave an average of 13.18 and $13.11 \%$ with an increment of 20.6 and $20.0 \%$ over the control, respectively, with no significant differences between them, whereas the lowest value was the control treatment which gave $10.93 \%$ as an average of both seasons of the study. In addition, the best influencing treatments on the total sugars \% were $\mathrm{HA}$ at $100 \mathrm{ppm}$ and $\mathrm{MJ}$ at $5 \mathrm{ppm}$ which gave an average of 15.75 and $15.73 \%$ with an increment of 20.6 and 20.4\%, respectively, with no significant differences between them followed by $\mathrm{MJ}$ at $10 \mathrm{ppm}$ which gave an average of $14.94 \%$ with an increment of $14.4 \%$ over the control treatment, whereas the lowest percentage was the control treatment which gave $13.06 \%$ as an average for both seasons of the study. Likewise, there were no significant differences between most of the treatments and the control in their effect on the percentage of non-reducing sugars.

\subsection{Anthocyanin content}

There was an increase in the anthocyanin content in both the peel and arils of the pomegranate fruits compared to the control during the two seasons of study. In addition, the treatments of MJ Surpassed the rest of the treatments in their effect on the anthocyanin content followed by HA treatments, whereas, the $\mathrm{K}$ treatments gave the lowest values (Fig. 9).

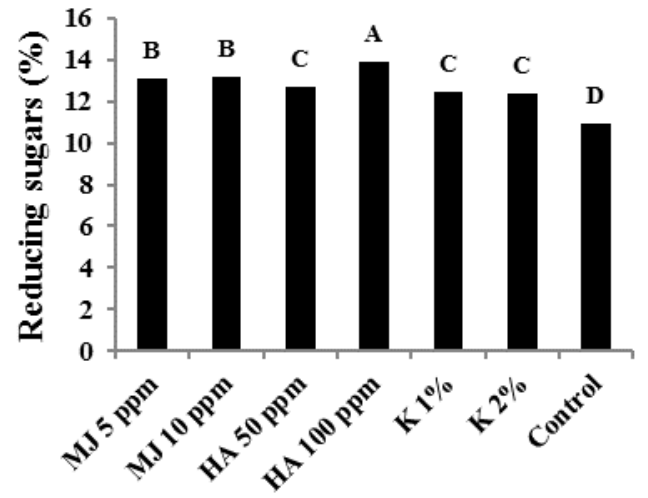

(A)
Treatments

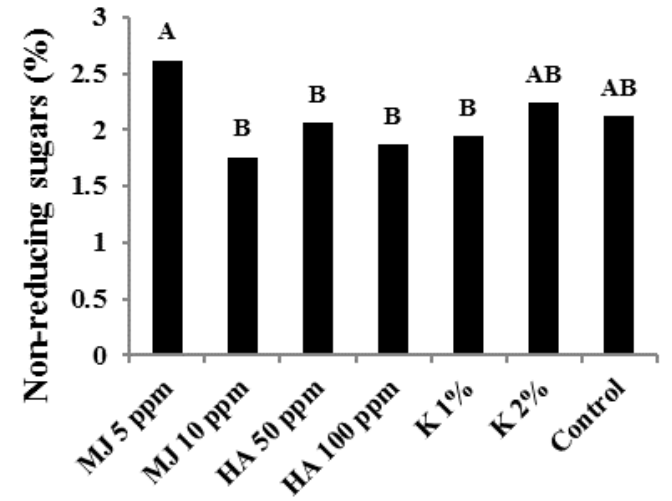

(B)
Treatments 


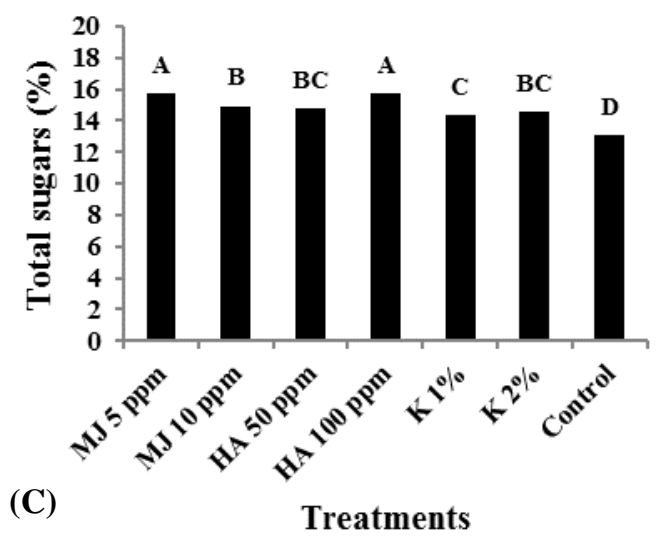

Figure 8. Effect of $(\mathrm{MJ}),(\mathrm{HA})$ and $(\mathrm{K})$ spraying on sugars content: $(\mathrm{A})$ reducing sugars $\%$, (B) non-reducing sugars $\%,(\mathrm{C})$ total sugars $\%$ of Manfalouty pomegranate cultivar during 2018 and 2019 seasons.

Likewise, the MJ at $10 \mathrm{ppm}$ treatment gave the highest value of anthocyanin content in both peel and arils of pomegranate fruits. They gave value of 113.8 and $8.6 \mathrm{mg}$ with an increment of 196.4 and $163.5 \%$ followed by MJ at 5 ppm treatment which gave the value of 77.1 and
$6.38 \mathrm{mg}$ with an increment of 100.8 and $95.7 \%$ over the control in both peel and arils, respectively as a general average for the two years of study. On the other side, the control treatment gave the lowest values.

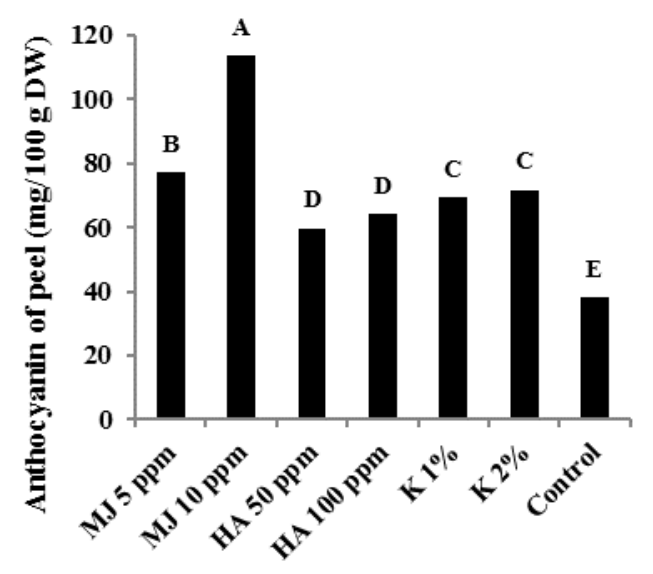

(A)

Treatments

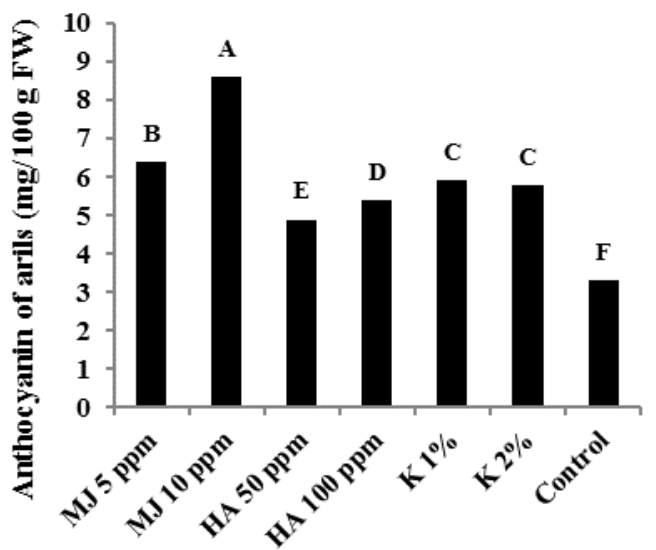

(B)
Treatments

Figure 9. Effect of (MJ), (HA) and $(\mathrm{K})$ spraying on anthocyanin content: (A) anthocyanin of peel (mg/100 g driy weight), (B) anthocyanin of arils (mg/100 g fresh weight) of Manfalouty pomegranate cultivar during 2018 and 2019 seasons. 


\section{Discussion}

Based on preceding reports with respect to the negative impacts of JAs on photosynthesis and plant growth (Wasternack and Hanse, 2013; Hakeem et al., 2014 and Yan et al., 2015), we were anticipating to record a diminished fruit growth and yield in response to MJ treatment, but fascinatingly our results showed the positive effects of this phytohormone on both yield and quality parameters of pomegranate fruit.As a sequence of exciting results, foliar application of pomegranate with MJ at $10 \mathrm{ppm}$ caused a significant increase in fruit qualitative parameters such as TSS, sweetness, juice content, phytochemicals, bioactive compounds including total anthocyanin and chlorophyll content and quantitative ones such as fruit weight and aril weight. Actually, MJ at 10 ppm not only enhanced phytochemical compounds and quality parameters of the fruit but also improved the productivity, demonstrating that MJ plays critical roles in different growth and developmental processes of the pomegranate trees and fruits.

It appears that MJ helps pomegranate trees to keep up photosynthesis capacity by directly closing the stomata during the warm hours of the days. In addition, MJ, by cross-talking with other phytohormones and affecting different metabolic routes, increases the facility of pomegranate trees in responding to environmental stimuli, and allows the fruit to slow down respiration rate and water loss and accumulate enough amounts of assimilates for growing under adverse growth conditions (Pareek et al., 2015). Moreover, Inferior levels of total acids and higher levels of soluble sugars rise the fruit sweetness and are very significant for producing pomegranates with a higher sensory quality (Wang et al., 2009; Fawole and Opara, 2013). It seems that MJ decreases the levels of insufficient oxidation in photosynthetic assimilates causing diminished total acidity. It has been stated that the endogenous jasmonates increase during ripening representing the role of this phytohormone in changing acids to sugars (Khan and Singh, 2007).

Different phenolics are of key anti-stress and antioxidant components donating in nutritional capacity of pomegranates (Tehranifar et al., 2010 and Çam et al., 2014). Some of these compounds are careful as the main components of crop quality parameters counting pigments, taste and nutritional quality. Vatanparast et al. (2012) reported that $0.5 \%$ of MJ meaningfully augmented the phenolic compound, antioxidant activity and the color of fruit peel of pomegranate fruits compared to control. Merikhi et al., 2019 concluded that foliar application with 0.5 mmol $\mathrm{L}^{-1}$ methyl jasmonate may be considered as an effective nonchemical method for enhancing pomegranate fruit quality attributes and phytochemical compounds. Additionally, García-Pastor et al. (2020) confirmed that MJ treatments enhanced arils color due to increased concentration of total and individual anthocyanins, at harvest and during storage. Appropriately, MJ treatments driven to build up of anthocyanins and other polyphenol compounds in several plants as a result of improved phenylalanine ammonialyase (PAL) activity and expanded expression of genes codifying enzymes involved in anthocyanin biosynthesis pathway (Jia et al., 2016; Wei et al., 2017).

Cracking is a physiological disorder that happens due to the different growth rats 
between skin and flesh of fruit (Yilmaz and Özgüren, 2006). There are several aspects that cause fruit cracking such as hot dry weather, soil moisture, climatic, tree nutrition and cultivars (Kumar et al., 2010; Sheikh and Manjula, 2012). The quick assimilation of water when irrigation is continued to severely stressed fruit leads to cracking of the skin as water is occupied to the aril and greater stress is placed on the water-deficient skin. It has also been proposed that asymmetrical stretching of the skin happens as the aril fills with water. This leads to splitting on the same side of the swelling aril (Galindo et al., 2014). This problem caused a noteworthy misfortune within the productivity of some pomegranate cultivars may reach more than 50\% (Sheik and Manjula, 2012). Applying biofertilizers such as Humic acids (HA) which considered the most divisions of humic substances (HS) and the foremost active components of soil and compost organic matter (Ferrara and Brunetti, 2010), can be valuable for expanding the productivity and quality of pomegranate fruits. Humic acid, a byproduct of plant decay, has various bio-stimulatory properties that work to reduce damage from abiotic stress (Canellas et al., 2015; Moghadam, 2015). It is additionally able intervene shifts in essential and secondary metabolism forms to balance development and increment water-use proficiency. Application of humic acid particularly at 100 ppm diminished fruit splitting of pomegranate under our conditions in both seasons of study. Our results in assention with the past investigates conducted on different pomegranate cultivars by (Ghanbarpour et al., 2019 and Nurbhanej, 2019).

Our results obviously showed that HA application particularly at $100 \mathrm{ppm}$ increased the productivity of pomegranate under our conditions in both seasons of study. The increases in total yield maybe related to the influence of HA fertilization as it aided in inspiring plant growth and subsequently yield by performing on mechanisms included in: cell respiration, photosynthesis, protein synthesis, water and nutrients uptake and enzyme activities, this result in permitting to the preceding studies specified by (Khattab et al., 2012; Lotfi et al., 2015; Moghadam, 2015; Hatami et al., 2018). Also our results in covenant with the previous researches showed on different pomegranate cultivars by (Khattab et al., 2012; 2014; Abd El-Rahman, 2017; Kamal et al., 2017; Mansour, 2018; Ghanbarpour et al., 2019; Nurbhanej, 2019), as they indicated that HA fertilization augmented the yield of pomegranate.

The nutrients plays main role in improving plant development and fruit quality occurrence in pomegranate. Fertilization is allowing for the main agricultural performs which had major sound effects on fruit quality, in this situation potassium is vital plant mineral nutrients having a significant effect on many human-healths related quality compounds in fruits and vegetable (Tiwari, 2005; Ashraf et al., 2010). Potassium is an important macronutrient in pomegranate and its concentration in peel and aril of pomegranate fruits was the highest associated to other macronutrients (Mirdehghan and Rahemi, 2007). It is also recognized as the excellence nutrient for its significant effects on quality aspects (Lester et al., 2006). Soares, et al., (2005) reported that potassium soil application significantly increased antioxidant activity and reduced oxidative impairment. Furthermore, the fruits chemical characteristics mainly total 
soluble solids, total sugars, ascorbic acid and anthocyanin contents plays a most important role in crop due to their essentiality in fruit quality and postharvest life of harvested produce (Aly et al., 2015).

For instance, to the effect of treatments, it is clear that all concentrations of potassium treatments meaningfully augmented the total yield/tree $(\mathrm{Kg})$, the quality of fruit and abridged cracking (\%) than the control in the two seasons. The greatest actual treatment which gave the lowest crack and highest yield with good quality of fruits was $\mathrm{K} 2 \%$ during the two seasons of study. Tehranifar and Tabar (2009) found that $\mathrm{K}$ application at the highest concentration considerably increased the peel and juice of fruit, acidity, total soluble solids and total sugar content than those in the other treatments. It also produced a considerably increased the content of anthocyanin, phenolic compounds and antioxidant activity of fruit juice. Mirdehghan and Vatanparast (2012) found that preharvest treatments of pomegranate trees with potassium may well be considered as appropriate tools to evade whiteness of pomegranate arils with higher bioactive compounds and antioxidant activity as compared to control fruit. Davarpanah et al. (2014) on "Malas-e-Saveh" pomegranate cultivar stated that foliar application of mono and di-potassium phosphate at concentration of $0.1 \%$ resulted in significant increase in yield/tree, fruit number, titrable acidity compared to control treatment. Likewise, foliar application of mono and di-potassium phosphate caused a significant improvement in aril juice and color intensity and total soluble solid. Ismail et al. (2018) detected that the uppermost values of total yield/tree, fruit weight, number of arils/fruit, TSS, total sugars and the minimum cracking values were gotten by application of potassium silicate at 5000 ppm on "Wonderful" pomegranate trees.

Optimistic influence of $\mathrm{K}$ fertilization on pomegranate fruit yield might be attributed to its noteworthy parts in different processes in plants containing biosynthesis of chlorophyll, proteins like cytochrome and ferredoxin, nitrogen fixation, electron transport chain complex, and structure of enzymes involved in nitrate absorption (Al-Bamarny et al., 2010; Marschner, 2012; Hamouda et al., 2016). Also, potassium increases synthesis of carboxylation enzyme, which stimulates $\mathrm{CO}_{2}$ fixation and increases photosynthesis (Almeselmani et al., 2009). In addition, Increase in fruit size after $K$ fertilization can be related to the vital roles of $\mathrm{K}$ in plants, in specific the role it plays in cell expansion that leads to the formation of a large central vacuole in fruit cells (Talaie, 2008). The increase in total anthocyanin contents as a result of $\mathrm{K}$ foliar application are in line with the results of Davarpanah et al. (2017); Chater and Garner (2018, 2019), who informed that the contents of anthocyanin in pomegranate increased by $\mathrm{K}$ fertilizers. Potassium plays crucial roles in anthocyanin synthesis through increasing the translocation of sugars into fruits, in addition to act as a cofactor and stimulator of some enzymes like UDP galactose: flavanoide-3-o-glicosil transferase (Delgado et al., 2006).

\section{Conclusion}

From the gotten results of the present study it could be recommended that spraying HA at $100 \mathrm{ppm}$ and $\mathrm{MJ}$ at $10 \mathrm{ppm}$ are considered the best in their effect on the yield components, fruit quality and anthocyanin content, however for decreasing the fruit cracking, it could be spraying the fruit with 
liquid $\mathrm{K}$ at $1 \%$ or $\mathrm{MJ} 10 \mathrm{ppm}$ compared to the rest of the treatments.

\section{References}

Abd El-Rhaman I.E. (2010) 'Physiological studies on cracking phenomenon of pomegranate', J. App. Sci. Res., 6(6): 696.

Abd El-Rhman I.E. (2017) 'Effect of magnetic iron and potassium humate on growth, yield and fruit quality of pomegranate trees in Siwa oasis', Egypt. Int. J. Environ., 6(3): 103-113.

Ahammed G.J., Xia X.J., Li X., Shi K., Yu J.Q.and Zhou Y.H. (2015) 'Role of brassinosteroid in plant adaptation to abiotic stresses and its interplay with other hormones. Curr. Protein Pept. Sci., 16: 462-473.

Ahmed F.F. and Morsy M.H. (1999) 'A new method for measuring leaf area in different fruit species', Minia J. Agric. Res. Develop. (19): 97-105.

Al-Bamarny S.F.A., Salman M.A.and Ibrahim Z.R. (2010) 'Effect of NAA, KNO3 and Fe on some characteristics of leaf and fruit of peach (Prunus persica L.) cv. early coronet', 14-16 September 2010; Zurich, Switzerland: World Food System-A Contribution from Europe.

Almeselmani M., Pant R.C. and Singh B. (2009) 'Potassium level and physiological response and fruit quality in hydroponically grown tomato', Inter. J. Vegetable Sci., 16: 85-99.

Aly M.A., Ezz T.M., Harhash M.M.M., Awad R.M. and Abou El-Maaty A.M. (2015) 'Effect of foliar potassium, boron treatments and girdling on growth, productivity and leaves chemical composition of table grape "Superior cv." covering with plastic sheets', Middle East J. Agric. Res., 4(2): 170-180.

Asghari M.R. and Zahedipour P. (2016) '24Epibrassinolide acts as a growth promoting and resistance-mediating factor in strawberry plants', J. Plant Growth Regul., 35: 722-729.

Ashraf M.Y., Gul A., Ashraf M., Hussain F. and Ebert G. (2010) 'Improvement in yield and quality of Kinnow (Citrus deliciosa $\mathrm{x}$ Citrus nobilis) by potassium fertilization', J. Plant Nutrition, 33: 1625-1637.

Association of Official Agricultural Chemicals (A.O.A.C.), (1995) 'Official Methods of Analysis of the A.O.A.C. ', $16^{\text {th }}$ Ed. Published by A.O.A.C. Washington D.C., USA.

Betemps, D.L., Fachinello J.C., Galarca S.P., Portela N.M., Remorini D., Massai R. and Agati G. (2012) 'Non-destructive evaluation of ripening and quality traits in apples using a multiparametric fluorescence sensor', J. Sci. Food Agric., 92: 1855-1864.

Çam, M., İçyer N.C.and Erdoğan F. (2014) 'Pomegranate peel phenolics: microencapsulation, storage stability and potential ingredient for functional food development', LWT-Food Sci. Technol., 55: 117- 123.

Canellas L.P., Olivares F.L., Aguiar N.O., Jones D.L., Nebbioso A., Mazzei P. and Piccolo A. (2015) 'Humic and fulvic acids as biostimulants in horticulture', Sci Hort., 196:15-27.

Chater J.M. and Garner L.C. (2018) 'Foliar nutrient applications to 'Wonderful' 
pomegranate (Punica granatum L.). II. Effects on leaf nutrient status and fruit split, yield and size', Scientia Hort., 242: 207-213.

Chater J.M. and Garner L.C. (2019) 'Foliar nutrient applications to 'Wonderful' pomegranate (Punica granatum L.). I. Effects on fruit mineral nutrient concentrations and internal quality', Scientia Hort., 244: 421-427.

Davarpanah S., Aakari M.A., Babalar M., Zarei M.and Aghayeh R.N.M. (2017) 'Effect of foliar application of phosphorus, potassium and iron on physical and chemical properties of pomegranate fruit', Jordan J. Agric. Sci., 13(3): 693-706.

Davarpanah S., Askari M.A., Babalar M., Hosseini M.S. and Beni M.A. (2014) 'Effect of foliar spray of mono and dipotassium phosphate on some quantitative and qualitative characteristic of pomegranate fruit (Punica granatum L. cv. Malas e Saveh) ', J. Hort. Sci., 28(3): 379-387.

Delgado R., González M.and Martín P. (2006) 'Interaction effects of nitrogen and potassium fertilization on anthocyanin composition and chromatic features of tempranillo grapes', Inter. J. Vine and Wine Science, 40: 141-150.

Fawole O.A. and Opara U.L. (2013) 'Efects of storage temperature and duration on physiological responses of pomegranate fruit', Ind. Crops Prod., 47: 300-309.

Ferrara G. and Brunetti G. (2010) 'Effects of the times of application of a soil humic acid on berry quality of table grape
(Vitis vinifera L.) cv Italia', Spanish J. Agric. Res., 8: 817-822.

Galindo A., Rodríguez P., Collado-González J., Cruz Z., Torrecillas E., Ondoño S., Corell M., Moriana A. and Torrecillas A. (2014) 'Rainfall intensifies fruit peel cracking in water stressed pomegranate trees', Agric. For Meteorol., 194: 2935.

García-Pastor M.E., Serrano M., Guillén F., Giménez M.J., Martínez-Romero D., Valeroa D. and Zapata P.J. (2020) 'Preharvest application of methyl jasmonate increases crop yield, fruit quality and bioactive compounds in pomegranate 'Mollar de Elche' at harvest and during postharvest storage', J. Sci. Food Agric., 100: 145-153.

Ghanbarpour E., Rezaei M. and Lawson S. (2019) 'Reduction of cracking in pomegranate fruit after foliar application of humic acid, calciumboron and kaolin during water stress', Erwerbs-Obstbau, 61: 29-37.

Hakeem K.R., Rehman R.U. and Tahir I. (2014) 'Plant signaling: understanding the molecular crosstalk', Springer, New York.

Hamouda H.A., Khalifa R.K.M. and ElDahshouri M.F. (2016) 'Yield, fruit quality and nutrients content of pomegranate leaves and fruit as influenced by iron, manganese and zinc foliar spray', Inter. J. Pharm. Tech. Res., 9: 46-57.

Hatami E., Shokouhian A.A., Ghanbari A.R. and Naseri L.A. (2018) 'Alleviating salt stress in almond rootstocks using of humic acid', Scientia Hort., 237: 296302. 
Heber D., Schulman R.N. and Seeram N.P. (2006) 'Pomegranates: ancient roots to modern medicine', CRC Press, Boca Raton.

Hegazi A., Samra N.R., El-Baz E.E.T., Khalil B.M. and Gawish M.S. (2014) 'Improving fruit quality of Manfalouty and Wonderfull pomegranates by using bagging and some spray treatments with gibberellic acid, calcium chloride and kaolin', J. Plant Production, Mansoura Univ., 5(5): 779-792.

Ismail M.H., Adb-Alhamid N., Sewrus E.S. and Nasr S. (2018) 'Improving fruit cracking resistance of Wonderful pomegranates', Arab Univ. J. Agric. Sci. Ain Shams Univ. Cairo, 26(2): 445-457.

Jia H., Zhang C., Pervaiz T., Zhao P., Liu Z., Wang B., Wang C., Zhang L., Fang J., and Qian J. (2016) 'Jasmonic acid involves in grape fruit ripening and resistant against Botrytis cinerea', Functional and Integrative Genomics, 16(1): 79-94.

Jin P., Zheng Y.H., Tang S.S., Rui H.J. and Wang C.Y. (2009) 'Enhancing disease resistance in peach fruit with methyl jasmonate', J. Sci. Food Agric., 89: 802-808.

Kamal H.M., Elisa M.A. and Mohammed A.A. (2017) 'Effect of some mineral compounds on yield and fruit quality of pomegranate', Biosci. Res., 14(4): 1197-1203.

Khan A. and Singh Z. (2007) 'Methyl jasmonate promotes fruit ripening and improves fruit quality in Japanese plum', J. Hort. Sci. Biotechnol., 82: 695-706.
Khattab M.M., Shaban A.E., El-Shrief A.H., and Mohamed A.S.E. (2012) 'Effect of humic acid and amino acids on pomegranate trees under deficit irrigation. I: Growth, flowering and fruiting', J. Hort. Sci. Orna. Plants, 4(3): 253-259.

Khattab M.M., Shaban A.E., El-Shrief A.H., and Mohamed A.S.E. (2014) 'Effect of humic acid and amino acids on pomegranate trees under deficit irrigation. II: Fruit quality', AmericanEurasian J. Agric. Environ. Sci., 14(9): 941-948.

Kucuker E., Ozturk B., Celik S.M. and Aksit H. (2014) 'Pre-harvest spray application of methyl jasmonate plays an important role in fruit ripening, fruit quality and bioactive compounds of Japanese plums', Sci. Hort., 176: 162 169.

Kumar R., Bakshi P. and Srivastava J.N. (2010) 'Fruit cracking: Challenging problem of fruit industry', Krishi sandesh.

Lees D.H. and Francis F.J. (1971) 'Quantitive methods for anthocyanins. VI: Flavonols and anthocyanins in cranberries', J. Food Sci., 36: 10561060.

Lester G.E., Jifon J.L. and Makus D.J. (2006) 'Supplemental foliar potassium applications with or without a surfactant can enhance netted muskmelon quality', Hort. Sci., 41(3): 741-744.

Lotfi R., Gharavi-Kouchebagh P. and Khoshvaghti H. (2015) 'Biochemical and physiological responses of Brassicanapus plants to humic acid 
under water stress', Russ. J. Plant Physiol., 62:480-486.

Mansour N.A.I. (2018) 'Promising impacts of humic acid and some organic fertilizers on yield, fruit quality and leaf mineral content of Wonderful pomegranate (Punica granatum L.) trees', Egypt. $J$. Hort., 45(1): 105-119.

Marschner H. (2012) 'Mineral nutrition of higher plants', 3rd ed. London, UK: Academic Press Limited. Harcourt Brace and Company, Publishers, London.

Meng X.H., Han J., Wang Q.and Tian S.P. (2009) 'Changes in physiology and quality of peach fruits treated by methyl jasmonate under low temperature stress', Food Chem., 114: 1028-1035.

Merikhi M., Asghari M.R. and Kavoosi B. (2019) 'Effect of methyl jasmonate foliar application on some qualitative attributes and phytochemical contents of 'Rabab' pomegranate fruit', Iranian J. Hort. Sci. Tech., 20(1): 11-20.

Mirdehghan S.H. and Vatanparast G. (2012) 'Avoiding the paleness of pomegranate arils by preharvest application of salicylic acid and potassium sulfate', Acta Hort., 1012: 815-820.

Mirdehghan S.H. and Rahemi M. (2007) 'Seasonal changes of mineral nutrients and phenolics in pomegranate (Punica granatum L.)', fruit. Sci. Hort., 111: 120-127.

Moghadam T.H.R. (2015) 'Humic acid as an ecological pathway to protect corn plants against oxidative stress', Biol. Forum., 7(1): 1704-1709.
Mukkun L. and Singh Z. (2009) 'Methyl jasmonate plays a role in fruit ripening of 'Pajaro' strawberry through stimulation of ethylene biosynthesis', Scientia Hort., 123(1): 5-10.

Nurbhanej K.H. (2019) 'Effect of biostimulants and biofertilizers on flowering, fruiting, yield and quality of pomegranate (punica granatum L) $\mathrm{cv}$. 'Bhagwa' 2781', Ph.D. Thesis, Department of Horticulture, College of Agriculture, Junagadh Agriculture University, Junagadh, India.

O'Grady L., Sigge G., Caleb O. and Opara U.L. (2014) 'Efects of storage temperature and duration on chemical properties, proximate composition and selected bioactive components of pomegranate (Punica granatum L.) arils', LWT-Food Sci. Technol., 57: 508-515.

Onayemi O.O., Neto C.C. and Heuvel J.E.V. (2006) 'The effect of partial defoliation on vine carbohydrate concentration and flavonoid production in cranberries', Hort. Sci., 41(3): 607-611.

Ozgen M.D., Serce C.and Kaya S. (2008) 'Chemical and antioxidant properties of pomegranate cultivars grown in Mediterranean region of Turkey', Food Chem., 111: 703-706.

Pareek S., Valero D. and Serrano M. (2015) 'Postharvest biology and technology of pomegranate', J. Sci. Food Agric., 95(12): 2360-2379.

Sarkhosh A., Zamani Z., Fatahi R. and Ebadi A. (2006) 'RAPD markers reveal polymorphism among some Iranian pomegranate (Punica granatum L.) genotypes', Sci. Hort., 111: 24-29. 
SAS institute, (2008) 'The SAS system for windows', release 9.2 Cary NC: SAS institute.

Sheikh M.K. and Manjula N. (2012) 'Effect of chemicals on control of fruit cracking in pomegranate (Punica granatum L.) var. Ganesh', Options Mediterranean, A, $2^{\text {nd }}$ International Sympo. On the Pomegranate, 103: 133135.

Snedecor G.W. and Cochran W.G. (1990) 'Statistical Methods, $8^{\text {th }}$ Edition', Iowa State University Press, p. 503.

Soares A.G., Trugo L.C. and Botrel N. (2005) 'Reduction of internal browning of pineapple fruit (Ananas comusus L.) by preharvest soil application of potassium', Postharvest Biology and Technology, 35: 201-207.

Sun Y., Asghari M. and ZahedipourSheshgelani P. (2019) 'Foliar spray with 24-epibrassinolide enhanced strawberry fruit quality, phytochemical content, and postharvest life', J. Plant Growth Regul., 25: 256.

Talaie A.R. (2008) 'Physiology of temperate zone fruit trees', $1^{\text {st }}$ ed. Tehran, Iran: Tehran university press.

Tehranifar A. and Tabar S.M. (2009) 'Foliar application of potassium and boron during pomegranate (Punica granatum) fruit development can improve fruit quality', Hort. Environ. Biotechnol., 50(3): 191-196.

Tehranifar A., Zarei M., Nemati Z., Esfandiyari B. and Vazifeshenas M.R. (2010) 'Investigation of physicochemical properties and antioxidant activity of twenty Iranian pomegranate
(Punica granatum L.) cultivars', Sci. Hort., 126: 180-185.

Tiwari K.N. (2005) 'Diagnosing deficiency and maximizing fruit crop productivity', Better crops, 89(4): 2931.

Vatanparast G., Mirdehghan S.H., Karimi H.R. and Vazifeshenas M.H. (2012) 'Foliar application of salicylic acid, methyl jasmonate and potassium sulfate on photosynthestic characteristics and fruit quality of pomegranate', Iran Agric. Res., 31(2): 23-34.

Wang H., Schauer N., Usadel B., Frasse P., Zouine M. and Hernould M. (2009) 'Regulatory features underlying pollination-dependent and independent tomato fruit set revealed by transcript and primary metabolite profling', Plant Cell, 21: 1428-1452.

Wang S.Y. and Zheng W. (2005) 'Preharvest application of methyl jasmonate increases fruit quality and antioxidant capacity in raspberries', Int. J. Food Sci. Technol., 40: 187-195.

Wang S.Y., Bowman L. and Ding M. (2008) 'Methyl jasmonate enhances antioxidant activity and flavonoid content in blackberries (Rubus sp.) and promotes anti-proliferation of human cancer cells', Food Chem., 107: 12611269.

Wasternack C. and Hanse B. (2013) 'Jasmonates: biosynthesis, perception, signal transduction and action in plant stress response, growth and development', Ann. Bot., 111: pp. 1021-1058. 
Wei J., wen X. and Tang L. (2017) 'Effect of methyl jasmonic acid on peach fruit ripening progress', Sci. Hort., 220: 206213.

Yan, Z., W. Zhang, J. Chen and X. Li (2015) 'Methyl jasmonate alleviates cadmium toxicity in Solanum nigrum by regulating metal uptake and antioxidative capacity' Biol. Plant, 59: pp. 373-381.

Yilmaz, C and A.I. Özgüren (2009). The effect of some plant nutrients, GA3 and pinolene treatments on yield, fruit quality and cracking on pomegranate. International Symposium on Pomegranate and Minor Mediterranean Fruits. Acta Hort. 818: pp. 205-212.

Yilmaz, C. and A. Özgüren (2006). The effects of some plant nutrients, gibberellic acid and pinolene treatments on the yield, fruit quality and cracking in pomegranate. Acta Hort., 818: pp. 205-212.

Zhou, M.L., X.B. Yang, Q. Zhang, M. Zhou, E.Z. Zhao, Y.X. Tang, X.M. Zhu, J.R. Shao and Y.M. Wu (2013) 'Induction of annexin by heavy metals and jasmonic acid in Zea mays. Funct. Integr. Genomics, 13: pp. 241-251. 